\title{
The Buckner Dam Site (41CE339) and Four Other Caddo Sites on Gum Creek in the Upper Neches River Basin, Cherokee County, Texas
}

Timothy K. Perttula

Heritage Research Center, Stephen F. Austin State University

Bo Nelson

Heritage Research Center, Stephen F. Austin State University

Mark Walters

Heritage Research Center, Stephen F. Austin State University

Follow this and additional works at: https://scholarworks.sfasu.edu/ita

Part of the American Material Culture Commons, Archaeological Anthropology Commons, Environmental Studies Commons, Other American Studies Commons, Other Arts and Humanities Commons, Other History of Art, Architecture, and Archaeology Commons, and the United States History Commons

Tell us how this article helped you.

This Article is brought to you for free and open access by the Center for Regional Heritage Research at SFA ScholarWorks. It has been accepted for inclusion in Index of Texas Archaeology: Open Access Gray Literature from the Lone Star State by an authorized editor of SFA ScholarWorks. For more information, please contact cdsscholarworks@sfasu.edu. 


\section{The Buckner Dam Site (41CE339) and Four Other Caddo Sites on Gum Creek in the Upper Neches River Basin, Cherokee County, Texas}

\section{Creative Commons License}

\section{(c) (1) \&}

This work is licensed under a Creative Commons Attribution-NonCommercial 4.0 International License 


\title{
The Buckner Dam Site (41CE339) and Four Other Caddo Sites on Gum Creek in the Upper Neches River Basin, Cherokee County, Texas
}

\author{
Timothy K. Perttula, Bo Nelson, and Mark Walters
}

\section{INTRODUCTION}

Due to recent droughty conditions in East Texas in 2010 and 2011, the water levels on the man-made lakes and reservoirs in the region have been steadily lowering. This decreasing water levels is cxposing considerable areas along the lakes that not only have been underwater for considerable periods of time since the lakes were constructed, but this new land exposure is also exposing and eroding archaeological sites that are now along the new lake shore boundaries. Such is the case at Lake Jacksonville, a small lakc on Gum Creek in Cherokee County, Texas, and newly recorded archaeological sites have been found along its shores. This article is a summary of efforts to document archaeological collections that have been reported from five sites at I ake Jacksonville.

\section{SETTING}

The five archaeological sites at Lake Jacksonvillc are along Gum Creek, or one of its tributaries. Gum Creek is a southward-flowing tributary to the Neches River, in the upper Neches River basin. They are all along the western boundary of the modern extent of the Pineywoods (see Diggs et al. 2006) and the eastern boundary of the Post Oak Savannah. The Pineywoods cover large parts of East Texas, have medium-tall to tall broadleaf dcciduous forests in more mesic habitats, and shortleaf and loblolly pines are common on upland finc sandy loam soils with adequate moisture. Bottomland conmunities along the major river and creek drainages contain a diverse hardwood and swamp forest (including cypress, tupelo, and sweet gum), with natural levees and alluvial terraces, point bar deposits, old stream channels, oxbow lakes, and backwater swamps. A less diverse bottomland hardwood conmunity is present along the smaller creeks and their tributaries.

The Post Oak Savannah is a narrow southwest-northeast trending woodland that marks an ecotone between the more xeric Blackland Prairie to the west and south (Diggs et al. 2006:Figure 2) and the more mesic Pineywoods to the east. The woodlands in the Post Oak Savannah consist of broadleaf deciduous forests, primarily including several species of oak as well as hickory and pecan. Small areas of tall grass prairie were present in this physiographic province see Diggs et al. 2006:Figure 5) that ran from the Colorado River on the west to near the Trinity River on the east. Bottomland communities along the rivers and major tributaries in the Post Oak Savannah had a diverse hardwood and/or swamp forest, including cypress, sweet gum, and other hardwoods that tolerant periodic flood waters, on natural levees and alluvial terraces, point bar deposits, old stream channels and oxbow lakes.

\section{THE SITES AND THEIR DOCUMENTED COLLECTIONS}

As previously mentioned, during normal pool elevations at Lakc Jacksonville, the five sites discussed in this article are under water. The Buckner Dam site (41CE.339), before construction of the lake, was located on an upland landform overlooking Gum Creek; part of the sitc is now visible on a sandbar below 
the Buckner Dam (Texas Historic Sites Atlas 2011). The Jacksonville Campground site (4ICE442) is situated at the confluence of Gum Crcek and Byrd Branch, on one end of a sandy ridge now used by the City of Jacksonville as a city park/campground. The third site, Cat Creek (41CE444), is along the shoreline of Lake Jacksonville, about $60 \mathrm{~m}$ west of an old channel of Gum Creek. The Piney Point site (41CE445) is ca. $50 \mathrm{~m}$ north of an old channcl of Cat Creek, a tributary to Gum Creek. The site was exposed along the shoreline, and this portion of the site has been heavily eroded by lake water action. Finally, the Mission site (41CE447) is ca. $199 \mathrm{~m}$ cast of an old channel of Gum Creek. The site did not receive its name because there is a Spanish mission at this location. Rather, there is a modern residence visible from the site that was built in 18 th century San Antonio mission architecture style, and thus the site was unfortunately dubbed the "Mission" site.

\section{Buckner Dam Site (41CE339)}

The Buckner Dam site had a substantial prehistoric Caddo component, based on the estimated size of the site $(6000 \mathrm{~m}$, or 1.5 acres) and the large ceramic vessel sherd collection ( $\mathrm{n}=670$ sherds, Table 1$)$. The vessel sherds were from grog-tempered vessels $(95.5 \%)$, with a small amount of sherds that were from vessels tempered with bone, or had hematite inclusions in addition to grog tcmper $(12.8 \%)$. About $20 \%$ of the tempered sherds had a sandy paste, suggesting the occasional usc by Caddo potters of a local naturally sandy clay; otherwise, locally available clay or silty paste clays were preferred in vessel manufacture. The plain to decorated sherd ratio of this ceramic assemblage is 1.51 .

The decorated sherds from the Buckner Dam site were dominated by utility ware sherds with brushing and brushed-incised ( $42 \%$ of all the decorated sherds) body decorations, along with incised sherds ( $33.3 \%$ of the decorated sherds) with various elements and motifs, and punctated sherds $19.0 \%$ of the decorated sherds). Fine ware engraved sherds were not abundant in the assemblage, comprising only

Table 1. The ceramic assemblage from the Buckner Dam site.

\begin{tabular}{llll}
\hline $\begin{array}{l}\text { Sherd Type/ } \\
\text { Decorative Type }\end{array}$ & No. & Percent & Percent with Bone Temper \\
\hline Plain rim & 15 & 2.2 & 0.0 \\
Plain body & 377 & 56.3 & 4.3 \\
Plain base & 11 & 1.6 & 25.0 \\
Decorated sherds & 267 & 40.3 & 4.6 \\
Brushed-Incised & 7 & 1.0 & 0.0 \\
Brushed & 105 & 15.7 & 4.5 \\
Neck Banded & 1 & 0.1 & 0.0 \\
Punctated & 24 & 3.5 & 11.8 \\
Incised-Punctated & 11 & 1.6 & 0.0 \\
Inciscd & 89 & 13.3 & 5.7 \\
Pinched & 10 & 1.5 & 0.0 \\
Engraved & 18 & 2.7 & 0.0 \\
\hline Totals & 670 & 100.0 & 4.5 \\
\hline
\end{tabular}


$6.7 \%$ of all the decorated sherds (Table 2). The frequency of the two decorated wares was also apparent in the proportion of rims: 16 utility ware rim sherds and only five fine ware rims (3.2:1); plain ware rims $(\mathrm{n}=15$, see Table 1) were almost as common as the utility ware rim sherds.

Table 2. Decorative elements in the Buckner Dam ceramic assemblage.

\begin{tabular}{|c|c|c|c|}
\hline Decorative method and element & Rim & Body & $\mathrm{N}$ \\
\hline \multicolumn{4}{|l|}{ Utility Ware } \\
\hline parallel brushed & - & 102 & 102 \\
\hline opposed brushed & - & 3 & 3 \\
\hline subtotal, brushed & - & 105 & 105 \\
\hline horizontal brushed [rim]-diagonal incised [body] & 1 & - & 1 \\
\hline parallel brushed-incised & - & 1 & 1 \\
\hline overlapping brushed-incised & - & 3 & 3 \\
\hline opposcd brushed-incised & - & 2 & 2 \\
\hline subtotal, brushed-incised & 1 & 6 & 7 \\
\hline cross-hatched incised lines & - & 1 & 1 \\
\hline single curvilinear line & - & 1 & 1 \\
\hline diagonal incised lines & 5 & 1 & 6 \\
\hline diagonal and vertical incised lines & 1 & - & 1 \\
\hline diagonal and horizontal incised lincs & 1 & - & 1 \\
\hline horizontal incised & 1 & - & 1 \\
\hline opposed incised lines & 1 & 10 & 11 \\
\hline parallel incised lines & - & 40 & 40 \\
\hline broad parallel incised lines & - & 1 & 1 \\
\hline closcly-spaced parallel incised lines & - & 1 & 1 \\
\hline widely-spaced parallel incised lines & - & 3 & 3 \\
\hline single straight incised line & - & 20 & 20 \\
\hline single straight, broad line, incised line & - & 2 & 2 \\
\hline subtotal, incised & 9 & 80 & 89 \\
\hline diagonal incised lines above tool punctated row & 1 & 1 & \\
\hline $\begin{array}{l}\text { diagonal incised lines and triangular zone of } \\
\text { tool punctates }\end{array}$ & 1 & - & 1 \\
\hline parallel lines adjacent to circular punctated zone & - & 2 & 2 \\
\hline $\begin{array}{l}\text { parallel lines adjacent to triangular zone of } \\
\text { fingernail punctates }\end{array}$ & - & 1 & 1 \\
\hline
\end{tabular}


Table 2. Decorative elements in the Buckner Dam ceramic assemblage, cont.

\begin{tabular}{|c|c|c|c|}
\hline Decorative method and element & $\operatorname{Rim}$ & Body & $\mathrm{N}$ \\
\hline parallel lines adjacent to tool punctated zone & - & 2 & 2 \\
\hline straight incised line adjacent to tool punctates & - & 4 & 4 \\
\hline subtotal, incised-punctated & 1 & 10 & 11 \\
\hline parallel neck bands & - & 1 & 1 \\
\hline horizontal pinched ridges & 1 & - & 1 \\
\hline parallel pinched rows & - & 3 & 3 \\
\hline vertical pinched ridges & - & 6 & 6 \\
\hline subtotal, pinched & 1 & 9 & 10 \\
\hline circular punctated rows & - & 1 & 1 \\
\hline fingernail punctated, rows & - & 1 & 1 \\
\hline single fingernail punctate & - & 1 & 1 \\
\hline linear tool punctated rows & - & 2 & 2 \\
\hline tool punctated rows & 4 & 12 & 16 \\
\hline tool punctated, frec & - & 2 & 2 \\
\hline single tool punctatc & - & 1 & 1 \\
\hline subtotal, punctated & 4 & 20 & 24 \\
\hline \multicolumn{4}{|l|}{ Eine Ware } \\
\hline narrow cross-hatched engraved zone & - & 1 & 1 \\
\hline closely-spaced curvilinear engraved lines & - & 1 & 1 \\
\hline diagonal engraved lines & 1 & - & 1 \\
\hline horizontal engraved lines & 2 & - & 2 \\
\hline horizontal and curvilinear areing lines & - & 2 & 2 \\
\hline horizontal and diagonal engraved lines & 2 & - & 2 \\
\hline opposed engraved lincs & - & 4 & 4 \\
\hline parallel engraved lines & - & 2 & 2 \\
\hline single straight engraved line & - & 2 & 2 \\
\hline single curvilinear engraved line & - & 1 & 1 \\
\hline Subtotal, engraved & 5 & 13 & 18 \\
\hline Totals & 21 & 246 & 267 \\
\hline
\end{tabular}


The decorated rim sherds provide an indication of the range of motifs and elements in the Buckner Dam site ceramic assemblage, as well as the popularity of particular kinds of decorations. In the utility wares, $56 \%$ of the 16 rims had incised decorations, including diagonal incised lines, opposed diagonal incised lines (Figure 1a), and horizontal and/or diagonal incised lines. These are probably from Maydelle Incised jars (see Suhm and Jelks 1962). Other common rim decorative treatments in the utility wares included jars with rows of tool punctations on the rim $(25 \%)$; these rows typically werc placed under the lip, at mid-rim, and then at the rim-body juncture; vessel bodies may have been plain or had any number of decorative methods applied to cover the exterior surface. Other rims among the utility wares includes one with horizontal brushing on the rim and diagonal incised lines on the vessel body; a Killough Pinched jar with horizontal pinched ridges covering the rim; and a jar rim with diagonal incised lines forming one side of an incised triangle, with the incised triangle filled with tool punctates (see Table 2). This particular rim may be from a Maydelle Incised vessel (see Suhm and Jelks 1962:Plate 52e). The neck banded jar sherd is from a LaRue Neck Banded vessel.

Utility ware vessel bodics in this assemblage were most commonly covered with brushing marks, most likely vertical in orientation. There were also vessels with various incised, punctated (free or randomly placed), and pinched body decorations (see Table 2). Incised-punctated vessel decorations were most likely confincd to the rim of vessels.

Among the fine ware sherds, the rims have either diagonal, horizontal, or diagonal engraved lines. The horizontal engraved sherds may be from Hickory Engraved vessels (see Suhm and Jelks 1962:Plate 36), which would suggest a Caddo occupation here that occurred prior to ca. A.D. 1300 , according to the best estimates on the age of this and related East Texas types such as Holly Fine Engraved, Weches Fingernail Impressed, Pennington Punctated-Incised, or Crockett Curvilinear Incised (cf. Story 2000). None of the other pre-A.D. 1300 East Texas ceramic types occurred in the Buckner Dam site collection, leaving open the possibility that horizontal engraved vessels may also date after ca. A.D. 1300, and not be exclusively associated with these carly ceramic types.

Other distinctive cngraved sherds, but found among the body sherds, were two sherds of the Poynor Engraved type. Thesc have horizontal and curvilinear arcing engraved lines (see Figure lc), and are probably part of curvilincar hatched-filled triangles, a common Poynor Engraved clcment (see Perttula 2011:Figure 6-15). There was also a body sherd with a narrow engraved zone filled with cross-hatched engraved lines (see Figure 1b). Such narrow cross-hatched or cross-hatched zones are a common feature in 14th and 15th century upper Neches River Caddo ceramic assemblages (see Perttula 2011:Figures 6-13 and 6-14).

In addition to the ceramic vessel sherds, there were five ceramic pipe sherds in the Buckner Dam sitc collections. Four are relatively thick (4.6-6.5 mm) elbow pipe stem sherds, one with an incised line on it, and the other is a bone-tempered elbow pipe bowl rim. The one incised elbow pipe stem sherd is from either an Var. B, Var. C, or Var. D elbow pipe form, varieties of pipes recently established in the upper Neches River basin (Perttula 2011:215 and Figure 6-23). Such elbow pipes were made and used by Caddo peoples between ca. A.D. 1400-1560.

Also notcworthy in the Buckner Dam collections was a single piece of daub. This suggests there may have been a thatch and clay-covered Caddo structure on the site during its occupation.

The chipped stone artifacts in the Buckner Dam site collection were meager. The few tools included a unifacially flaked Godley dart point made from a gray chert and a Gary point preform, also of gray chert. Their occurrence at the site suggests it was used by a Woodland period group of people sometime between ca. 2500-1200 years ago, perhaps as a hunting camp. Lithic raw materials and chipped stone tools were knapped at the site, as evidenced by a small amount of lithic debris: quarlzite $(n=2)$, petrified wood $(n=7)$, brown chert $(n=1)$, dark gray chert $(n=2)$, and gray chert $(n=2)$. The gray and dark gray cherts were from non-local sources, perhaps Neches River or Trinity River gravels, while the other raw materials were likely gathered from local stream gravel sources. 


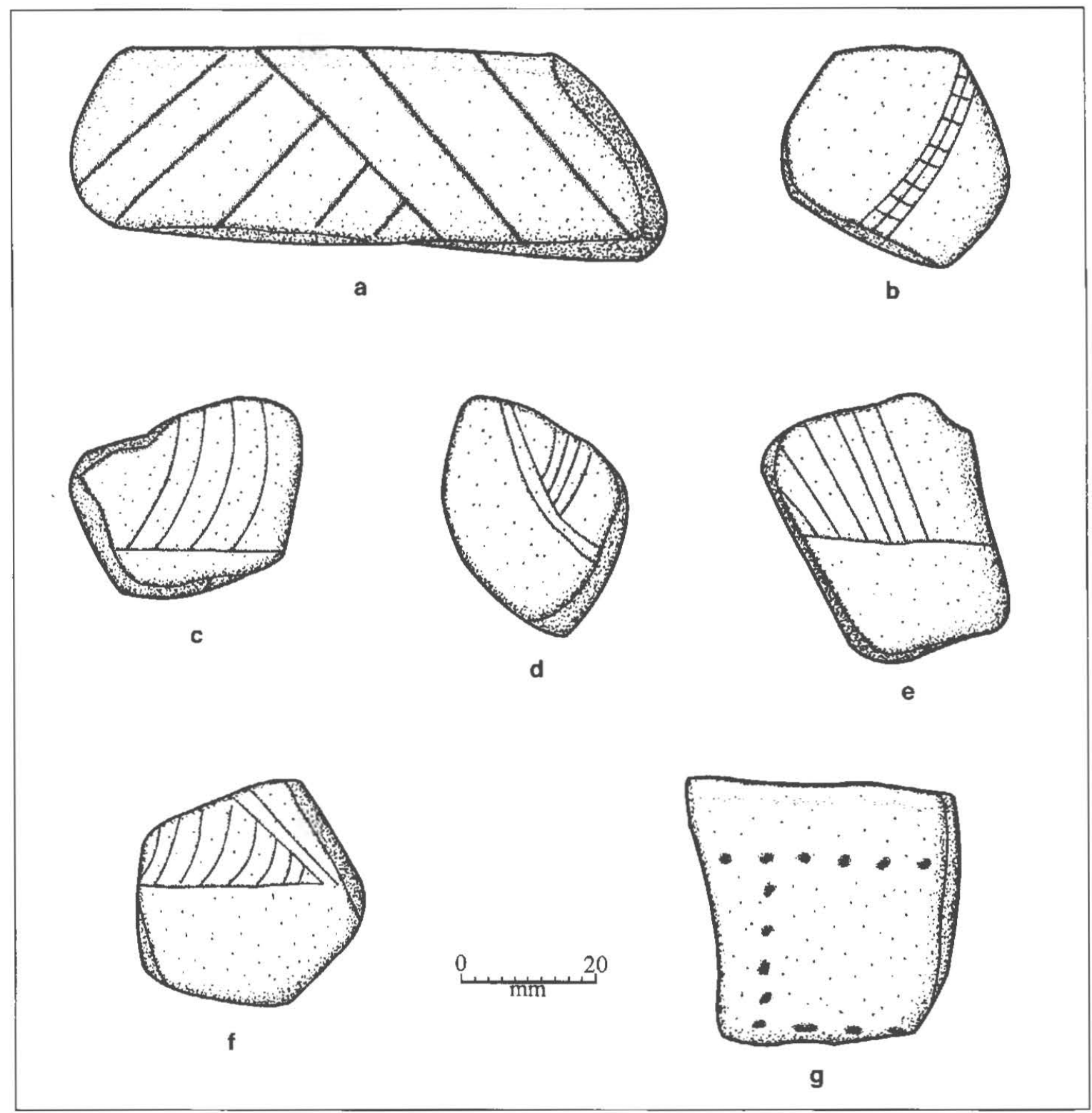

Figure 1. Selected decorated sherds from the Lake Jacksonville sites: a, opposed diagonal inciscd rim sherd; $b$, crosshatched engraved zone; c, cf. Poynor Engraved body sherd; d, curvilinear and vertical arcing engraved lines, bottle sherd; e, opposed engraved lines; f, cf. Poynor Engraved body sherd; g, tool punctated rim. Provenience: a-c, 4ICE339; d, 41 C.F.442; e-g, 41 CE445.

\section{Jacksonville Campground (41CE442)}

The artifacts documented from the Jacksonville Campground site indicated that there were both Woodland and Caddo occupations here. The Woodland period occupation was denoted by five sandy paste Goose Creek Plain, var. unspecified body sherds. Sherds of this Woodland period type were also noted at the Cat Creek site.

The Caddo ceramic assemblage had 55 plain rim $(n=1)$, body $(n=53)$, and base $(n=1)$ sherds as well as 24 decorated rim and body sherds. The P/DR is 2.29 . The Jacksonville Campground Caddo sherds were grog-tempered. but $5.1 \%$ were noted to also contain burned and crushed bone temper inclusions. 
Almost $80 \%$ of the decorated sherds from the site were from utility ware vessels, with the remaining $20 \%$ coming from fine ware bowls, carinated bowls, and bottles. Over $60 \%$ of the utility wares had brushed decorations, including a horizontal brushed rim, and parallel $(n=10)$ and overlapping $(n=1)$ brushed marks on vessel bodies. Sherds from vessels with incised decorations were also common, including parallel lined $(\mathrm{n}=2$ ), cross-hatehed (one rim), and a rim/body sherd with opposed incised lincs; this latter sherd may be from a Maydelle Incised jar. Two other utility ware sherds had incised-punctated elements, including zones of tool punctations adjacent to straight or cross-hatched incised elements. One body sherd had a row of tool punctations across it.

The five fine ware sherds from the Jacksonville Campground site wcre body sherds, one from a bottle. This sherd had opposed arcs of closely-spaced engraved lines (see Figure 1d), possibly from a Poynor Engraved bottle (Suhm and Jelks 1962: Plate 63e,g). Two other engraved sherds had straight or parallel engraved lines, another had a hatched zone, and the last engraved sherd had a cross-hatched engraved zone or column element.

A few chipped stone artifacts were documented in the collection. They comprised temporally undiagnostic lithic debris and a core fragment, the product of some chipped stone tool manufacturing efforts during the course of one or both prehistoric components. These materials include a local brown chert core fragment and 10 pieces of lithic debris. All hut one of these pieces are from locally available quartzite (50\%) and petrified wood $(40 \%)$; the one flake from a non-local raw material is a non-cortical piece of grayish-brown chert.

\section{Cat Creek (41CE444)}

Only a small number of artifacts were documented from the Cat Creek site. These included a hematite pitted stone, a quartzite hammerstone, and five pieces of lithic debris ( 1 hrown-dark brown chert: 2 petrified wood; 1 brown chert; and I quartzite); $80 \%$ of the lithic debris had cortical remnants.

There were also five plain ccramic body sherds in the collection. Three were from grog or grog-bonetempered vessels, while the other two were from a plain sandy paste Goose Creek Plain, var. unspecified vessel (cf. Aten and Bollich 2011). Such vessels are found in Woodland period contexts (ca. 500 B.C. to A.D. 700) in East Texas.

\section{Piney Point (41CE445)}

Caddo ceramic sherds were abundant in the documented collection from the Pincy Point site, with 191 plain sherds (seven rim sherds, 175 body sherds, and nine base sherds) and 80 rim and body sherds with decorations. The $\mathrm{P} / \mathrm{DR}$ is 2.39 . The sherds were almost exclusively from grog-tempered vessels, although $5.5 \%$ of the sherds ( $5.8 \%$ of the plain sherds and $5 \%$ of the decorated sherds) were bone-tempered.

Among the decorated sherds. almost $89 \%$ were from utility ware jars, and only $11.3 \%$ were from fine ware bowls or carinated bowls (Table 3). Half of the utility ware sherds had brushing on them, primarily parallel (vertical on the vessel body?), including one that had both brushed marks and incised lines parallel to the brushing. Sherds from vessels with incised lines comprised $25 \%$ of the decorated sherd assemblage; the incised sherds emphasized straight line and geometric elements. Tool punctated rim and body sherds accounted for $6.3 \%$ of the decorated sherds, and these consisted of rows of tool punctates, typically horizontal to the rim, but in one case both horizontal and vertical punctations comprised the decorative element on the sherd (see Figure 1g).

Five percent of the decoraled sherds from the Piney Point site had incised-punctated elements (see Table 3). These had incised triangles filled with either tool punctations or small circular punctations. There were two utility ware sherds that had appliqued elements (i.e., straight appliqued ridge or appliqued fillet) associated with either incised lines or tool punctations. The appliqued clements were employed to divide the body of utility ware jars into pancls filled with decorations executed with another method such as zones of tool punctations or panels filled with opposed incised lines. 
72 Journal of Northeast Texas Archaeology 36 (2012)

Table 3. Decorative methods and elements in the Piney Point site ceramic assemblage.

\begin{tabular}{|c|c|c|c|}
\hline Decorative method and element & Rim & Body & $\mathrm{N}$ \\
\hline \multicolumn{4}{|l|}{ Utility Ware } \\
\hline appliqued ridge adjacent to a tool punctated zone & - & 1 & 1 \\
\hline appliqued fillet and opposed parallel incised lines & - & 1 & 1 \\
\hline parallel brushed & - & 33 & 33 \\
\hline overlapping brushed & - & 3 & 3 \\
\hline horizontal brushed & - & 1 & 1 \\
\hline opposed brushed & - & 1 & 1 \\
\hline curvilinear brushed & - & 1 & 1 \\
\hline parallel brushed-overlapping parallel incised & - & 1 & 1 \\
\hline diagonal inciscd lines & 1 & 1 & 2 \\
\hline diagonal opposed lines & - & 1 & 1 \\
\hline parallel incised lines & - & 12 & 12 \\
\hline straight incised line & - & 5 & 5 \\
\hline $\begin{array}{l}\text { horizontal-diagonal incised lines and incised zonc } \\
\text { filled with circular punctations }\end{array}$ & - & 1 & 1 \\
\hline $\begin{array}{l}\text { triangular incised zone filled with circular } \\
\text { punetations }\end{array}$ & - & 1 & I \\
\hline $\begin{array}{l}\text { straight incised lines adjacent to tool punctated } \\
\text { zone }\end{array}$ & - & 2 & 2 \\
\hline tool punctates in rows & - & 4 & 4 \\
\hline tool punctates in horizontal and vertical rows & 1 & & 1 \\
\hline \multicolumn{4}{|l|}{ Fine Ware } \\
\hline curvilinear engraved lines & - & 1 & 1 \\
\hline horizontal engraved lines & - & 2 & 2 \\
\hline opposed engraved lines & - & 2 & 2 \\
\hline parallel engraved lines & - & 3 & 3 \\
\hline triangular element with arcing lincs & - & 1 & 1 \\
\hline Totals & 2 & 78 & 80 \\
\hline
\end{tabular}


The fine ware sherds are primarily straight line or geometric designs (see Figure le and Table 3), although there is one sherd with curvilinear lines that may be from a bottle. The most distinctive engraved sherd (see Figure 1f) is one that compares favorably to several varieties of Poynor Engraved (Pcrttula 2011:Figure 6-64), including var. Blackburn, var. Cook, and var. Lang. These particular varietics are most common in the early and middle parts of the Frankston phase, from ca. A.D. 1400-1560 (Perttula 2011:Tahle 6-37).

The lithic artifacts documented from the Piney Point site included several tools and tool fragments as well as lithic debris. The tools were a quartzite Gary point preform, indicative of use of the site in Woodland period times, two petrified wood biface fragments, and a polished celt fragment made from a dark gray diorite; this material came from source areas in the Ouachita Mountains of southeastern Oklahoma (see Banks 1990), or was traded/exchanged from a Ouachita or Red River Caddo group to one of the East Texas Caddo communities living in the upper Neches Rivcr basin.

Lithic debris $(n=33)$ from the site was primarily a product of the knapping of local lithic raw materials, among them quartzite $(n=16)$, petrified wood $(n=7)$, red chert $(n=3)$, and hrown chert $(n=1)$. Cortical flakes comprised $80 \%$ of the lithic debris from these matcrials, clearly indicating that the initial reduction of pebbles and cobbles was an important knapping activity at the Piney Point site, probably to produce flakes usahle for tools. Non-local lithic debris was a brown to dark brown chert $(n=5)$ and a gray chert.

\section{Mission (41CE447)}

The prehistoric Caddo archaeological materials documented from the Mission site consisted of one piece of lithic debris (hrownish-gray chert, from a non-local raw material source) and 79 ccramic vessel sherds. This included 59 plain body sherds, four plain base sherds, and 16 decorated rim and body sherds. The P/DR for this assemblage, although not of optimal sample size, is 3.94 .

The ceramics were predominantly grog-tempered; $10.1 \%$ of the sherds also had crushed and hurned bone added to the vessel paste as a temper. All of the decorated sherds were from utility ware jars, including brushed (50\%), incised ( $44 \%)$, and one incised-punctated body sherd $(6.3 \%)$. This sherd had an inciscd circle filled with tool punctations. Two of the incised sherds were rims with either diagonal or horizontal lines. The brushed sherds had parallel brushing marks on them, probably from cooking vessels with vertical brushing on the bodies.

\section{SUMMARY}

The documentation of the collections from fivc aboriginal sites along Gum Creek in the upper Neches River basin in East Texas indicates that the five sites had both Woodland period (ca. 2500-1200 years ago) and Caddo era occupations and associated material culture remains. Sparsely occupied Woodland components at the Buckner Dam (41CE339), Jacksonville Campground (41CE342), Cat Creek (41CE344), and Piney Point (41CE445) sites are marked by a few plain sandy paste Goose Creek Plain, var. unspecified ceramic sherds and Godley and Gary dart points. These sites must have been the scene of a few small camps episodically occupied for short periods of time, and not the scene of more permanent Woodland habitation. Such sites may be present along the Neches River and/or larger tributarics to the river, where resources were more predictable and seasonally abundant.

The prehistoric Caddo occupations at the Lake Jacksonville sites, especially those documented at the Buckner Dam and Jacksonville Campground sites, likely had more substantial use, probably as farmsteads or small harnlets that would have becn dispersed along Gum Creek and in the upper Neches River valley and small and large tributaries. The Caddo occupation appears to have been extensive, at least

during some part of the Caddo era in East Texas. Ceramic comparisons between the four sites with Caddo ceramic vessel sherds (Table 4) suggest - if one ignores the P/DR values, which are suspect in the case 
Table 4. Ceramic comparisons of the Lake Jacksonville sites.

\begin{tabular}{llllll}
\hline Sites & P/DR & \% brushed & \% wet paste & \% bone temper & N \\
\hline 41 CE447 & 3.94 & 50.0 & 50.0 & 10.1 & 79 \\
41 CE445 & 2.39 & 50.0 & 40.0 & 5.5 & 271 \\
41 CE442 & 2.29 & 50.0 & 29.2 & 5.1 & 79 \\
41 CE339 & 1.51 & 42.0 & 53.2 & 4.5 & 670 \\
\hline
\end{tabular}

of the Jacksonville Campground and Mission sites because they do not meet the 200 plain and decorated sherd sample size threshold for reliability) - that these sites may well be from a generally contemporaneous community of Caddo peoples living along Gum Creek whose material culture included a distinctive array of ceramic characteristics.

These characteristics include the manufacturc of ceramic vessels primarily using local clays and crushed sherds (grog) as the predominant temper, with little use of bone temper (4.5-10.1\% of the sherds). These vessels were intended for domestic, and household, use. Utility wares, both sherds from brushed jars and vessels with wet paste decorations, including incised, punctated, incised-punctated, and pinched methods, make up the vast bulk of the decorated vessels (between $79.2-100 \%$ of the sherds) from the four Gum Creek sites. Maydelle Incised and Killough Pinched types are present in the assemblages. There are also post-A.D. 1400 Poynor Engraved sherds from two of the sites, and elbow pipes at the Buckner Dam site. Taken in concert with the fact that brushed sherds comprise hetween $42-50 \%$ of the decorated sherds - and such proportions of brushed sherds in assemblages are seen only in the earliest part of the Late Caddo Frankston phase (Perttula 2011:Table 6-38) in the upper Neches River basin-the Lake Jacksonville sites likely were occupied between ca. A.D. 1400-1480. As such, it is concluded that the Lake Jacksonville Caddo sites were part of an upper Neches River basin grog-tempered ceramic tradition shared by Caddo peoples specific to this area (Perttula 2011:315-318 and Figure 6-71).

\section{REFERENCES CITED}

Aten, L. E. and C. N. Bollich

2011 Early Ceramic Sites of the Sabine Lake Area, Coastal Texas and Louisiana. Studies in Archeology 43. Texas Archeological Research Laboratory, The University of Texas at Austin.

Banks, L. D.

1990 From Mountain Peaks to Alligator Stomachs: A Review of Lithic Sources in the Trans-Mississippi South, the Southern Plains, and Adjacent Southwest. Memoir No. 4. Oklahoma Anthropological Society, Norman.

Diggs Jr., G. M., B. L. Lipscomb, M. D. Reed and R. J. O'Kennon

2006 Illustrated Flora of East Texas, Volume One: Introduction, Pteridophytes, Gymnosperms, and Monocotyledons. Sida, Botanical Miscellany, No. 26. Botanical Research Institute of Texas, Fort Worth. 
Perttula, T. K.

2011 The Ceramic Artifacts from the Lang Pasture Site (41AN38) and the Place of the Site within an Upper Neches River Basin Caddo Ceramic Tradition. In Archeological Investigations at the Lang Pasture Site (4IAN38) in the Upper Neches River Basin of East Texas, assembled and edited by T. K. Perttula, D. B. Kelley, and R. A. Ricklis, pp. 145-320. Archeological Studies Program Report No. 129, Texas Department of Transportation, Environmental Affairs Division, Austin.

Story, D. A.

2000 Introduction. In The George C. Davis Site, Cherokee County, Texas, by H. P. Newell and A. D. Krieger, pp. 1-31.2nd Edition. Society for American Archaeology, Washington, D.C.

Suhm, D. A., and E. B. Jelks (editors)

1962 Handbook of Texas Archeology: Type Descriptions. Special Publication No. 1, Texas Archeological Society, and Bulletin No. 4, Texas Memorial Museum, Austin. Reprinted in 2009, Gustav's Library, Davenport, Iowa.

Texas Historic Sites Atlas

2011 http://nueces.thc.state.tx.us, Accessed June 26, 2011. 